fications which are part of syndromic disorders mainly affecting tissues of neuroectoderm origin.

As mentioned by Dr. Alcolado, mitochondrial genetics are characterized by some remarkable peculiarities. MtDNA molecules within a cell can interact and can complement each other. They undergo replicative segregation; which means that the proportions of mutant and wild-type mtDNA (heteroplasmy) that are distributed to daughter cells can fluctuate resulting in a progressive drift towards either pure mutant or wild-type mtDNA (homoplasmy). Thus, even subjects with identical nuclear genotypes, such as monozygotic twins, can differ in their mitochondrial genotype, a fact which should be kept in mind with respect to the discordance of Type 1 diabetes in "identical" twins. The association between MELAS and diabetes or, in other words, between the mitochondrial tRNA $^{\text {Leu (UUR) }}$ point mutation at nt 3243 and diabetes is a model for pathogenesis [12]. This mutation is usually found in a heteroplasmic form. It seems to produce increased amounts of a novel unprocessed RNA species, which is proposed to be incorporated into mitochondrial ribosomes, rendering them functionally deficient [12]. With respect to replication the tRNA ${ }^{\text {Leu (UUR) }}$ mutation has a marked advantage against the wild-type genome as recently demonstrated in cell culture studies [13]. Threshold expression is a further feature of mtDNA genetics. This means that different organs rely on energy production to a different degree and therefore also have different thresholds with respect to the nature and the percentage of mutated mtDNA. Up to now it is unclear what factors regulated mitochondrial disease expression resulting in encephalomyopathies on one site and in endocrinopathies such as diabetes on the other site. As our understanding of the mitochondrial genetics matures, valuable insights into common disease mechanisms are likely to emerge also in the field of mutual effects between the nucleus and the mitochondrion.

Yours sincerely,

\section{K.-D. Gerbitz}

\section{References}

1. Dorner G, Mohnike A, Steindel E (1975) On possible genetic and epigenetic modes of diabetic transmission. Endokrinologie 66: 225-227

2. Ballinger SW, Shoffner JM, Hedaya EV et al. (1992) Maternally transmitted diabetes and deafness associated with a $10.4 \mathrm{~kb}$ mitochondrial DNA deletion. Nature Genetics 1:11-15

3. van den Ouweland JMW, Lemkes HHPJ, Ruitenbeek W et al. (1992) Mutation in mitochondrial tRNA ${ }^{\text {Leu (UUR) }}$ gene in a large pedigree with matemally transmitted type II diabetes and deafness. Nature Genetics 1: 368-371

4. Reardon W, Ross RJW, Sweeney MG et al. (1992) Diabetes mellitus associated with a pathogenic point mutation in mitochondrial DNA. Lancet 340: 1376-1379

5. Obermaier-Kusser B, Paetzke-Brunner I, Enter C et al. (1991) Respiratory chain activity in tissues from patients (MELAS) with a point mutation of the mitochondrial genome (tRNA ${ }^{\text {Leut }}$ (UUR) FEBS Lett 286: 67-70

6. Majander A, Suomaleinen A, Vettenranta K et al. (1991) Congenital hypoplastic anemia, diabetes and severe renal tubular dysfunction associated with a mitochondrial DNA deletion. Pediatr Res 30: 327-330

7. Zupanc ML, Moraes CT, Shanske S et al. (1991) Deletions of mitochondrial DNA in patients with combined features of KearnsSayre and MELAS syndromes. Ann Neurol 29: 680-683

8. Superti-Furga A, Schoenle E, Tuchschmid P et al. (1993) Pearsons bone marrow pancreas syndrome with insulin-dependent diabetes mellitus, progressive renal tubulopathy, organic aciduria and elevated fetal haemoglobin caused by deletion and duplication of mitochondrial DNA. Eur J Pediatr 152:44-50

9. Rötig A, Bessis JL, Romero N et al. (1992) Maternally inherited duplication of the mitochondrial genome in a syndrome of proxi- mal tubulopathy, diabetes mellitus and cerebellar ataxia. Am J Hum Genet 50: 368-371

10. Inui K, Fukushima H, Tsukamoto $\mathrm{H}$ et al. (1992) Mitochondrial encephalomyopathies with the mutation of the mitochondrial tRNA $^{\text {Len }(U U R)}$ gene. J Pediatr 120:62-66

11. Zeviani M, Gellera C, Antozzi C et al. (1991) Maternally inherited myopathy and cardiomyopathy: association with mutation in mitochondrial tRNA ${ }^{\text {Leu (UUR) }}$. Lancet 338: 143-147

12. Schon EA, Koga Y, Davidson M et al. (1992) The mitochondrial tRNA ${ }^{\text {Leu (UUR) }}$ mutation in MELAS: a model for pathogenesis. Biochim Biophys Acta 1101: 206-209

13. Yoneda M, Chomyn A, Martinuzzi A et al. (1992) Marked replicative advantage of human mtDNA carrying a point mutation that causes the MELAS encephalomyopathy. Proc Natl Acad Sci USA 89:11164-11168

Dr. K-D. Gerbitz

Institute für Klin. Chemie und Diabetesforschung

Krankenhaus München-Schwabing

Kölner Platz 1

W-8000 München 40

Germany

\section{Pulmonary function in Type 1 (insulin-dependent) diabetes mellitus}

Dear Sir,

Dr. K.Strojek and co-workers evaluated the influence of Type 1 (insulin-dependent) diabetes mellitus upon the main pulmonary function tests [1]. They demonstrated no significant disturbance of spirometric parameters, while the diffusing capacity in the diabetic patients with microvascular complications was lower than in both the diabetic patients without complications and the control group.

We assessed the pulmonary function in a group of 68 ( 38 female, 30 male) young diabetic subjects with and without persistent microalbuminuria (defined as albumin excretion rate $>20 \mu \mathrm{g} \cdot \mathrm{min}^{-1}$. $1.73 \mathrm{~m}^{2-1}$ ); their ages ranged from 6.01 to 22.0 (mean \pm SD $15.25 \pm$ 6.77) years, the height from 117 to $179(147.1 \pm 29.6) \mathrm{cm}$ and the duration of disease from 1 to $247(59.31 \pm 74.17)$ months. The diabetic subjects showed no retinopathy or peripheral and autonomic neuropathy. None of the subjects smoked. We subdivided the subjects into two groups according to the presence of persistent microalbuminuria. Persistent microalbuminuria was defined as an albumin excretion rate greater than $20 \mu \mathrm{g} / \mathrm{min}$ in at least three overnight urine collections taken during the previous year,

Moreover, we subdivided the subjects into three groups according to their glycated haemoglobin levels $\left(\mathrm{HbA}_{1 \mathrm{c}}<8.5 \%, \mathrm{HbA}_{1 \mathrm{c}} 8.5-\right.$ $\left.10.0 \%, \mathrm{HbA}_{\mathrm{Ic}}>10.0 \%\right)$.

We performed the same measurements as Strojek and co-workers and our subjects, considered as a whole and divided into the different groups, showed normal values. Our data revealed no significant deviation of lung function from normal parameters in Type 1 diabetes. Moreover, the presence of microalbuminuria, as well as the quality of metabolic control, did not seem to influence the pulmo nary function.

In childhood and adolescence pulmonary function seems to be normal in subjects with and without microalbuminuria. Probably, the young age can partially explain our results.

On the other hand, other authors [2-4] have demonstrated that among the long-term complications, the limited joint mobility (perhaps a clinical marker of abnormal collagen), is often present in subjects with abnormal lung volumes. In our series, no patient suffered from limited joint mobility.

We fully agree with the conclusion of Strojek and co-workers [1], but we suggest an alternative explanation: the disturbances of dynamic compliance could be due to a genetic factor, perhaps involving an abnormality in collagen structure, which can be linked to the genetic predisposition to Type 1 diabetes. In order to clarify this 
point, we suggest that the study of pulmonary function should be extended to groups of diabetic patients suffering from limited joint mobility with and without other chronic complications.

Yours sincerely,

A. Verrotti, F. Chiarelli, M. Verini and G. Motgese

\section{References}

1. Strojek K, Ziora D, Sroczynski JW, Oklek K (1992) Pulmonary complications of type 1 (insulin-dependent) diabetic patients. Diabetologia 35: 1173-1176

2. Schnapf BM, Banks RA, Silverstien JJ, Rosenbloom AL, Chesrocon SE, Longhlin GM (1984) Pulmonary function in insulindependent diabetes mellitus with limited joint mobility. Am Rev Respir Dis 130: 930-932

3. Buckingham B, Perejda AJ, Sandborg C, Kershnar AK, Uitto J (1986) Skin, joint and pulmonary changes in type 1 diabetes mellitus. Am J Dis Child 140: 420-423

4. Madacsy L (1987) Joint and pulmonary changes in diabetes. Am J Dis Child 141:244-245

Dr. A. Verrotti

Department of Pediatrics

University of Chieti

Ospedale Pediatrico

Via Nicolini 11

I-66100 Chieti

Italy

\section{Response from the authors}

Dear Sir,

The problem of pulmonary abnormalities in diabetic patients remains an open issue. We welcome the analysis of Dr. Verrotti et al. on pulmonary function tests in a group of young Type 1 (insulin-dependent) diabetic patients. In our opinion the presence of pulmonary disturbances may depend on the selection of examined subjects.

The results obtained by Dr. Verrotti et al. do not exclude our observations [1]. Dr. Verrotti has examined a younger group of patients with shorter duration of diabetes. No clinical manifestation of angiopathy (i. e. retinopathy or overt nephropathy) was found in his group of subjects. Persistent microalbuminuria alone is the symptom of early stages of nephropathy [2]. Therefore, patients with microalbuminuria alone may not demonstrate diffusing capacity abnormalities which we found in patients with advanced stages of late diabetic complications [1].

We agree with Dr. Verrotti that coexisting limited joint mobility may be an additional factor which could deteriorate pulmonary function as shown by Schnapf et al. [3] who found reduced lung volume in diabetic patients. Patients with limited joint mobility were excluded from our study. Despite the normal lung volume we observed reduced dynamic compliance in diabetic patients.

Dr. Verrotti's hypothesis that dynamic compliance disturbances may be due to genetically-dependent collagen abnormalities is very interesting. In our opinion dynamic compliance disturbances may be an effect of accelerated collagen aging reported previously by Hamlin et al. [4]. Our point of view also appears to be confirmed by the results of the follow-up study of Lange et al. [5].

Yours sincerely,

K. Strojek and D.Ziora

\section{References}

1. Strojek K, Ziora D, Sroczynski JW, Oklek K (1992) Pulmonary complications of type 1 (insulin-dependent) diabetic patients. Diabetologia 35: 1173-1176

2. Mogensen CE, Chachati A, Christensen CK et al. (1986) Microalbuminuria: an early marker of renal involvement in diabetes. Uremia Investigation 9: 85-95

3. Schnapf BM, Banks RA, Silverstien JJ, Rosenbloom AL, Chesrocon SE, Loghlin GM (1984) Pulmonary function in insulin-dependent diabetes mellitus with limited joint mobility. Am Rev Respir Dis 130: 930-932

4. Hamlin CR, Kohn RR, Lushin JH (1985) Apparent accelerated aging of human collagen in diabetes mellitus. Diabetes $24 ; 902-$ 904

5. Lange P, Groth S, Mortensen J et al. (1990) Diabetes mellitus and ventilatory capacity: a five years follow-up study. Eur Respir J 3 : $288-292$

Dr. K. Strojek

Department of Internal and Occupational Disease

Silesian Academy of Medicine

ul. 3-go Maja 13/15

PL-41-800 Zabrze

Poland 